\title{
OPTIMASI OUTPUT DUAL AXIS SOLAR TRACKER MENGGUNAKAN METODE ASTRONOMI BERBASIS SMART RELAY
}

\author{
Budi Triyono, Yuli Prasetyo, dan Hendrik Kusbandono \\ Jurusan Teknik, Politeknik Negeri Madiun \\ J1. Serayu No. 84, Madiun 63133, Indonesia \\ ${ }^{*}$ E-mail: buditriyono@pnm.ac.id
}

\begin{abstract}
Abstrak
Upaya mengatasi terbatasnya energi listrik yaitu penggunaan energi terbarukan. Salah satu energi terbarukan yang berasal dari energi matahari. Pengaplikasian energi listrik yang berasal dari energi matahari pun cukup beragam seperti lampu penerangan jalan, penyuplai energi listrik untuk rumah tangga, battery charging, back up pembangkit listrik untuk industri, heater kolam renang, pompa air, dan lainnya. Dalam penggunaannya, panel surya banyak dipasang statik dan tidak memperhitungkan titik optimal pancaran sinar matahari. Hal ini menyebabkan intensitas cahaya matahari yang diterima kurang optimal. Sehingga mengakibatkan energi listrik yang dihasilkan tidak maksimal. Oleh karena itu diperlukan suatu sistem yang dapat mengendalikan panel surya secara otomatis dan mengikuti arah pergerakan cahaya matahari. Metode ini menggunakan sensor sudut berupa potensiometer untuk elevation dan rotary encoder sebagai sensor sudut azimuth. Hasil yang diperoleh dari penelitian ini memiliki nilai tegangan maksimal saat pergerakan mengikuti sinar matahari adalah $22 \mathrm{~V}$. Nilai tegangan keluaran dari panel surya lebih besar pada saat mengikuti pergerakan matahari yaitu $22 \mathrm{~V}$ sedangkan saat kondisi panel surya diam hanya $21 \mathrm{~V}$.
\end{abstract}

Kata kunci: energi terbarukan, panel surya, dual axis, solar tracker, metode astronomi

\begin{abstract}
The effort to overcome the limited electrical energy is the use of renewable energy. One of the renewable energies that comes from solar energy. The application of electrical energy derived from solar energy is also quite diverse, such as street lighting, electricity supply for households, battery charging, backing up power plants for industry, swimming pool heaters, water pumps, and others. In its use, many solar panels are installed statically and do not take into account the optimal point of the sun's rays. This causes the intensity of sunlight received to be less than optimal. So that the resulting electrical energy is not optimal. Therefore we need a system that can control solar panels automatically and follow the direction of the movement of sunlight. This method uses an angle sensor in the form of a potentiometer for elevation and a rotary encoder as an azimuth angle sensor. The results obtained from this study have a maximum voltage value when the movement follows the sun's rays is $22 \mathrm{~V}$. The value of the output voltage from the solar panel is greater when following the movement of the sun, which is $22 \mathrm{~V}$ while when the solar panel is at rest it is only $21 \mathrm{~V}$.
\end{abstract}

Keywords: renewable energy, solar panels, dual axis, solar tracker, astronomical methods

\section{Pendahuluan}

Energi matahari salah satu yang lebih dilirik karena ketersediaannya yang melimpah, walaupun hanya pada waktu-waktu tertentu saja. Aplikasi penggunaannya pun cukup beragam, seperti battery charging, penerangan jalan umum, pembangkit listrik untuk rumah tangga, sistem pemanas pada kolam renang, dan lainnya [1]-[3]. Keuntungan penggunaan energi alternatif ini adalah dalam hal perawatan dan bebas polusi [4]. Salah satu alat yang memanfaatkan energi matahari adalah panel surya. Panel surya bekerja mengubah energi cahaya menjadi energi listrik [5], [6]. Panel surya menghasilkan arus listrik DC (arus searah). Kendala utama pada panel surya adalah efisiensinya yang masih relatif rendah [7], [8]. Dalam penggunaannya, panel surya banyak dipasang statis dan tidak memperhitungkan titik optimal pancaran sinar matahari [9]. Hal ini menyebabkan intensitas cahaya matahari yang diterima kurang optimal [10]. Energi listrik yang dihasilkan dari solar tracker akan maksimal apabila panel surya selalu tegak lurus terhadap arah datangnya sinar matahari [11], [12]. Dengan kata lain, panel surya harus mengikuti arah pergerakan cahaya matahari [13], [14]. Oleh karena itu diperlukan suatu sistem yang dapat mengendalikan panel surya secara otomatis agar tetap tegak lurus terhadap arah datangnya sinar matahari. Penelitian ini menggunakan smart relay untuk mengatur rotasi motor DC yang berfungsi sebagai penggerak panel 
surya. Penelitian ini membahas tracker panel surya menggunakan metode astronomi berbasis smart relay.

\section{Metode}

Dalam penelitian ini terbagi kedalam beberapa bagian metode penelitian yaitu tahap perencanaan, skema penelitian dan perancangan alat.

\subsection{Penentuan Longitude, Latitude dan Timezone}

Penelitian ini menggunakan program Zelio Soft 2 untuk menerapkan metode astronomi pada panel surya [15] Zelio Soft 2 adalah sebuah software yang digunakan untuk pemrograman smart relay zelio. Zelio Soft 2 ini menggunakan bahasa pemrograman diagram Ladder dan FBD (Functional Block Diagram).

Politeknik Negeri Madiun memiliki koordinat geografis 7³8'51.2"S 111³1'36.4"E. Pembulatan menjadi 7³8'S dan $111^{\circ} 31^{\prime} \mathrm{E}$. Kemudian dirubah menjadi longitude dan latitude menggunakan rumus yang terdapat di program Zelio Soft 2, pada FBD suntrack [16]:

$$
\begin{aligned}
h & =100 x\left(m+\left(\frac{n}{60}\right)\right) \\
& =100 x\left(7+\left(\frac{38}{60}\right)\right) \\
& =-764 \text { (Latitude) }
\end{aligned}
$$

(Jika terletak di selatan atau barat, bernilai negatif)

$$
\begin{aligned}
h & =100 x\left(m+\left(\frac{n}{60}\right)\right) \\
& =100 x\left(111+\left(\frac{31}{60}\right)\right) \\
& =11152 \text { (Longitude) }
\end{aligned}
$$

Garis bujur dijadikan sebagai dasar penentuan pembagian waktu di seluruh bumi. Setiap jarak 15 derajat ke arah bujur timur atau ke arah bujur barat akan menunjukkan selisih waktu sebanyak 1 jam (60 menit). Kota Madiun terletak di 111 BT, sehingga untuk mencari timezone digunakan rumus :

$$
\begin{aligned}
\text { Timezone } & =\left(\frac{\text { Garis bujur }}{15}\right) \\
& =\left(\frac{111}{15}\right) \\
& =+7,4 \mathrm{jam} \\
& =+444 \text { menit }
\end{aligned}
$$

\subsection{Skema Penelitian}

Beberapa alat yang digunakan adalah smart relay zelio SR3B261BD, panel surya, sensor sudut, relay dc, kabel
NYAF $0,75 \mathrm{~mm}$, motor aktuator dan motor power window.

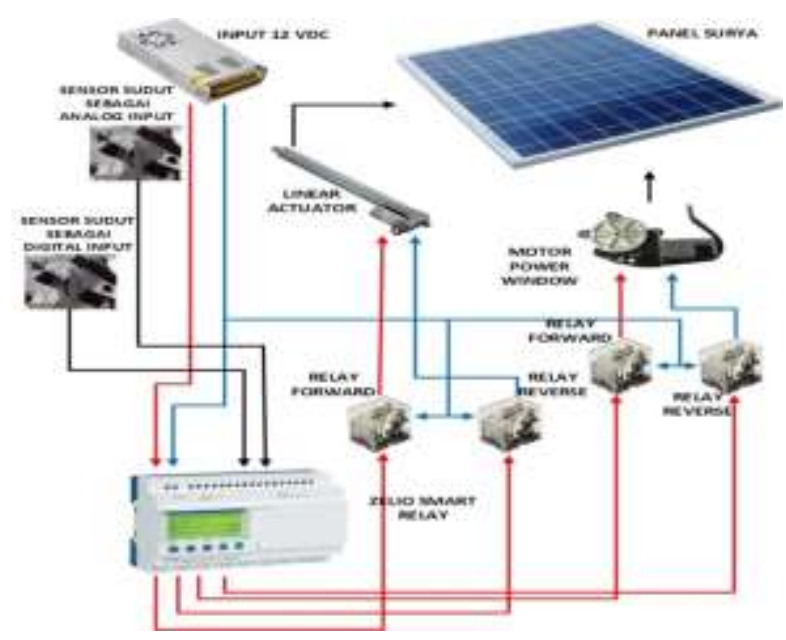

\section{Gambar 1. Skema Dual Axis Solar Tracker}

Fungsi dari rangkaian tersebut berdasarkan skema rangkaiannya adalah sebagai berikut :

1. Zelio Smart Relay dalam skema rangkaian tersebut digunakan kontrol utama perintah input dan output.

2. Sensor sudut potensiometer digunakan sebagai input analog pada Zelio Smart Relay.

3. Sensor sudut rotary encoder digunakan sebagai input digital pada Zelio Smart Relay

4. Relay DC $12 \mathrm{~V}$ digunakan untuk mengatur gerak motor aktuator dan motor power window.

5. Motor aktuator dan motor power window digunakan sebagai penggerak panel surya.

6. Panel surya digunakan untuk mengubah energi matahari menjadi energi listrik.

\subsection{Perancangan Kerangka Alat}

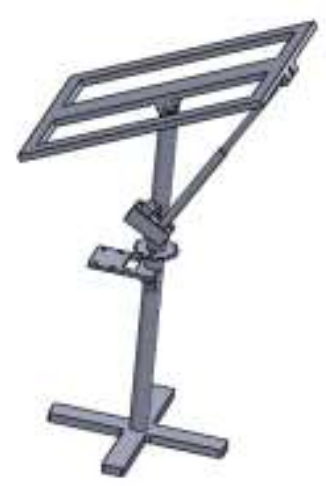

Gambar 2. Perancangan kerangka alat

Gambar 2 menjelaskan tentang kerangka alat yang digunakan untuk sistem. Pada kerangka alat ini terdapat aktuator dan motor power window untuk menggerakkan panel surya. 


\section{Hasil dan Analisa}

Hasil dan analisa dari pengujian sistem ini terbagi menjadi beberapa bagian. Pertama pengujian sistem tracking dimana sistem ini diuji berdasarkan lama tracking dalam 1 hari. Kedua pengujian aktuator dan motor power window. Pengujian ini digunakan untuk mengetahui kinerja dari aktuator dan motor power window saat proses tracking. Ketiga adalah data pengujian saat keadaan statis (diam) dan keadaan tracking.

Data pengujian dual axis solar tracker dapat dilihat pada tabel 1. Tabel 1 menjelaskan lama sistem pelacakan sinar matahari dalam satu hari dimulai dari data tracking ON dan berakhir pada tracking OFF. Dari pengujian ini diketahui bahwa setiap hari matahari mengalami pergerakan. Sistem ini dapat membuat panel surya mengikuti pergerakan matahari.

Tabel 1. Data Pengujian Sistem Tracking

\begin{tabular}{cccc}
\hline Tanggal/Bulan/Tahun & $\begin{array}{c}\text { Tracking } \\
\text { ON (WIB) }\end{array}$ & $\begin{array}{c}\text { Tracking } \\
\text { OFF } \\
\text { (WIB) }\end{array}$ & Lama Tracking \\
\hline $01 / 01 / 2020$ & 05.44 & 18.17 & 12 Jam 30 Menit \\
$01 / 02 / 2020$ & 05.57 & 18.24 & 12 Jam 27 Menit \\
$01 / 03 / 2020$ & 06.02 & 18.17 & 12 Jam 15 Menit \\
$01 / 04 / 2020$ & 06.00 & 18.01 & 12 Jam 01 Menit \\
$01 / 05 / 2020$ & 06.01 & 17.50 & 11 Jam 49 Menit \\
$01 / 06 / 2020$ & 06.05 & 17.46 & 11 Jam 41 Menit \\
$01 / 07 / 2020$ & 06.10 & 17.51 & 11 Jam 41 Menit \\
$01 / 08 / 2020$ & 06.10 & 17.57 & 11 Jam 47 Menit \\
$01 / 09 / 2020$ & 05.59 & 17.56 & 11 Jam 57 Menit \\
\hline
\end{tabular}

Pengujian berikutnya adalah pengujian aktuator dan pengujian motor power window. Pengujian aktuator menggunakan sumber 12 VDC pada aktuator dan menghubungkannya dengan program zelio soft 2 . Hasil pengujian aktuator seperti pada tabel 2. Pengujian ini menghasilkan sudut pergerakan aktuator untuk menggerakkan panel surya. Pada tabel 2 terlihat di jam 12.30 WIB bahwa aktuator mengalami pergerakan sudut sebesar $52,2^{0}$. Hal ini menunjukkan bahwa sistem panel surya ini dapat mengikuti pergerakan matahari.

Pengujian motor power window menggunakan sumber 5VDC pada motor power window dan menghubungkannya dengan program zelio soft 2 . Hasil pengujian motor power window dapat dilihat pada tabel 3 . Pengujian ini menghasilkan sudut pergerakan motor power window untuk menggerakkan panel surya. Pada tabel 3 terlihat di jam 12.30 WIB bahwa motor power window mengalami pergerakan sudut sebesar $13,4^{0}$. Hal ini menunjukkan bahwa sistem panel surya ini dapat mengikuti pergerakan matahari. Pergerakan sudut actuator ini digunakan untuk mengetahui pergerakan matahari dari utara ke selatan. Pergerakan sudut motor power window digunakan untuk mengetahui pergerakan matahari dari timur ke barat.
Tabel 2. Data Pengujian Aktuator

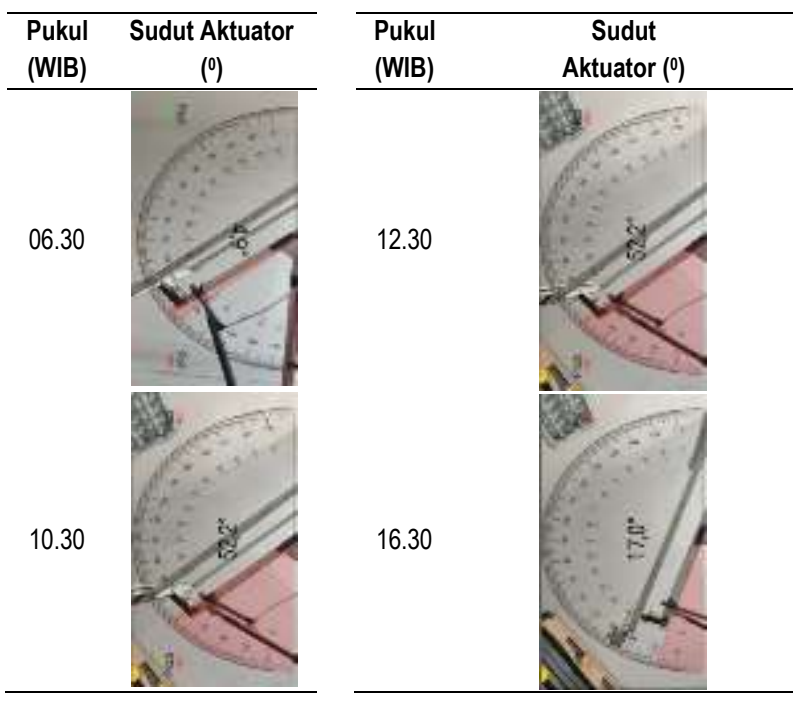

Tabel 3. Data Pengujian Motor Power Window

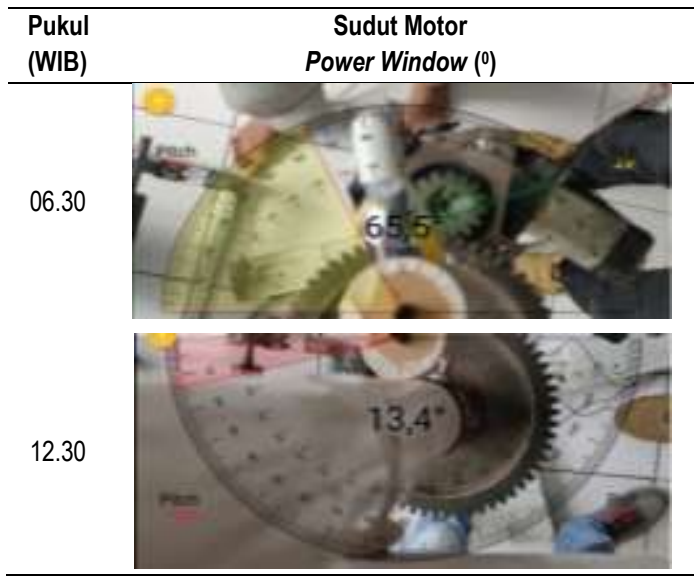

Tabel 4. Data Pengujian Kondisi Statis

\begin{tabular}{ccccc}
\hline No & $\begin{array}{c}\text { Waktu } \\
\text { (WIB) }\end{array}$ & $\begin{array}{c}\text { Tegangan } \\
\text { (V) }\end{array}$ & $\begin{array}{c}\text { Sudut } \\
\text { Kemiringan } \\
\text { Utara - } \\
\text { Selatan (0) }\end{array}$ & $\begin{array}{c}\text { Sudut } \\
\text { Kemiringan } \\
\text { Timur - } \\
\text { Barat (0) }\end{array}$ \\
\hline 1 & 09.00 & 21 & 89,9 & 50 \\
2 & 10.00 & 21 & 89,9 & 50 \\
3 & 11.00 & 21 & 89,9 & 50 \\
4 & 12.00 & 21 & 89,9 & 50 \\
5 & 13.00 & 21 & 89,9 & 50 \\
6 & 14.00 & 20 & 89,9 & 50 \\
7 & 15.00 & 20 & 89,9 & 50 \\
\hline
\end{tabular}

Pengujian terakhir adalah pengujian berdasarkan kondisi panel surya. Kondisi statis berarti kondisi saat panel surya dalam keadaan diam (statis). Pada kondisi ini dilihat hasil keluaran (output) dari dual axis solar tracker. Data pengujian sistem dalam kondisi statis terlihat pada tabel 4 .

Pengujian berikutnya dalam kondisi tracking atau pergerakan panel surya untuk mengikuti arah matahari. Arah pergerakan tracking ada dua yaitu dilihat dari sudut 
kemiringan utara-selatan dan kemiringan timur-barat Pada kondisi ini juga dilihat hasil tegangan output dari dual axis solar tracker. Data pengujian system dalam kondisi statis terlihat pada tabel 5. Pada tabel 5 menunjukkan bahwa kondisi tracker dapat dilakukan dengan baik. Tegangan keluaran hasil kondisi tracking lebih besar daripada kondisi statis. Data analog pada tabel 5 menunjukan data sensor pada sistem. Data analog atau data sensor ini bersifat linier dengan sudut kemiringan Timur ke Barat. Perubahan sudut kemiringan ini menunjukkan pergerakan panel surya mengikuti sinar matahari.

\section{Tabel 5. Data Pengujian Kondisi Tracking}

\begin{tabular}{cccccc}
\hline No & $\begin{array}{c}\text { Waktu } \\
\text { (WIB) }\end{array}$ & $\begin{array}{c}\text { Tegangan } \\
\text { (V) }\end{array}$ & Analog & $\begin{array}{c}\text { Sudut } \\
\text { Kemiringan } \\
\text { Utara - } \\
\left.\text { Selatan ( }{ }^{\circ}\right)\end{array}$ & $\begin{array}{c}\text { Sudut } \\
\text { Kemiringan } \\
\text { Timur - } \\
\text { Barat ( }\end{array}$ \\
\hline 1 & 09.00 & 21,5 & 37 & 89,9 & 64 \\
2 & 10.00 & 21,2 & 43 & 89,9 & 77 \\
3 & 11.00 & 22,0 & 55 & 89,9 & 84 \\
4 & 12.00 & 21,2 & 67 & 89,9 & 89 \\
5 & 13.00 & 21,0 & 79 & 89,9 & 95 \\
6 & 14.00 & 21,5 & 91 & 89,9 & 100 \\
7 & 15.00 & 21,0 & 103 & 89,9 & 114 \\
\hline
\end{tabular}

\section{Kesimpulan}

Sensor sudut elevation dan sensor sudut azimuth sudah bekerja dengan baik. Hal ini terlihat dari data analog pada tabel 5 yang mengalami perubahan. Program tracking dapat dimulai dan berakhir secara otomatis sesuai tempat yang diinginkan dengan memasukkan longitude, latitude, dan timezone pada FBD sunrise sunset. Pada pengujian sistem tracking menghasilkan nilai tegangan keluaran lebih besar dari pada pengujian statis. Maksimal nilai tegangan keluaran saat tracking (pelacakan) adalah $22 \mathrm{~V}$ dan maksimal nilai saat statis adalah $21 \mathrm{~V}$.

Untuk pengembangan alat selanjutnya dapat digunakan sensor lain yang lebih akurat dan dapat diterapkan dengan skala beban yang besar.

\section{Referensi}

[1]. A. Acakpovi, N. Yaw, and D. Babbo, "Low Cost TwoAxis Automatic Solar Tracking System," Commun. Appl. Electron., vol. 3, no. 8, pp. 46-53, 2015, doi: $10.5120 /$ cae2015652015.

[2]. B. Kumar Bharti, "Dual Axis Solar Tracking System," Imp. J. Interdiscip. Res., vol. 2, no. 4, pp. 2454-1362, 2016, [Online]. Available: http://www.onlinejournal.in.

[3]. Y. Prasetyo, B. Triyono, and A. Choirul Arifin, "Optimalisasi Daya Output Dual Axis Solar Tracker Dengan Metode Umbrella System,” J. Geuthèë Penelit. Multidisiplin, vol. 02, no. 02, pp. 267-274, 2019.
[4]. A. Md. Abdul Wadud, T. Zaman, F. Rabbee, and R. Rahman, "Renewable Energy: An Ideal Solution of Energy Crisis and Economic Development in Bangladesh," vol. 13, no. 15, 2013.

[5]. Y. Prasetyo, B. Triyono, H. N. K. Ningrum, R. J. K. Haryo, N. A. H., and W. Muchsin, "Penerapan Automatic Transfer Switch Pada Sistem Irigasi Di Desa Rejosari Kabupaten Madiun," JATI EMAS (Jurnal Apl. Tek. dan Pengabdi. Masyarakat), vol. 4, no. 2, p. 99, 2020, doi: 10.36339/je.v4i2.313.

[6]. I. Winarno and F. Wulandari, "Solar Tracking System Single Axis Pada Solar Sel Untuk Mengoptimalkan Daya Dengan Metode Adaptive Neuro- Fuzzy Inference System ( Anfis )," Semin. Nas. Sains dan Teknol., no. November, pp. 1-10, 2017.

[7]. J. K. Tharamuttam and A. K. Ng, "Design and Development of an Automatic Solar Tracker," Energy Procedia, vol. 143, pp. 629-634, 2017, doi: 10.1016/j.egypro.2017.12.738.

[8]. Y. Prasetyo, B. Triyono, H. Kusbandono, A. Tranggono, and A. Salim, "Optimization of Solar Panel Output Using Smart Relay,” vol. 5, no. 4, pp. 78-80, 2020.

[9]. M. Hejna, A. Jorapur, J. S. Song, and R. L. Judson, "High accuracy label-free classification of kinetic cell states from holographic cytometry," bioRxiv, vol. 1, no. 7, 2017, doi: 10.1101/127449.

[10]. A. Julisman, I. D. Sara, and R. H. Siregar, "Prototipe Pemanfaatan Panel Surya Sebagai Sumber Energi Pada Sistem Otomasi Stadion Bola," J. Karya Ilm. Tek. Elektro, vol. 2, no. 1, pp. 35-42, 2017.

[11]. S. Ozcelik, H. Prakash, and R. Challoo, "Two-axis solar tracker analysis and control for maximum power generation," Procedia Comput. Sci., vol. 6, pp. 457-462, 2011, doi: 10.1016/j.procs.2011.08.085.

[12]. N. D. Watane and R. A. Dafde, "Automatic Solar Tracker System,” Int. J. Sci. Eng. Res., vol. 4, no. 6, pp. 93-100, 2013.

[13]. Y. Rizal, S. H. Wibowo, and Feriyadi, "Application of solar position algorithm for sun-tracking system," Energy Procedia, vol. 32, pp. 160-165, 2013, doi: 10.1016/j.egypro.2013.05.021.

[14]. A. S. Al-ammri, F. I. M. Al-attar, and F. F. Ahmad, "Performance Test of Two-Axis Solar Tracker System with Distinct Tracking Strategies," AASCIT J. Energy, vol. 2 , no. 5, pp. 57-60, 2015.

[15]. A. A. Rafiq, "Optimalisasi Smart Relay Zelio sebagai Kontroler Lampu dan Pendingin Ruangan," J. Teknol. Elektro, vol. 8, no. 2, pp. 95-100, 2017, [Online]. Available:

https://publikasi.mercubuana.ac.id/files/journals/4/article s/1602/public/1602-3606-1-PB.pdf.

[16]. S. A. A. Shufat, E. Kurt, and A. Hancerlioğulları, "Modeling and design of azimuth-altitude dual axis solar tracker for maximum solar energy generation," Int. J. Renew. Energy Dev., vol. 8, no. 1, pp. 7-13, 2019, doi: 10.14710/ijred.8.1.7-13. 